\title{
メダカの卵括よび仔魚に対するカドミウムの毒性および 蓄積性に及ぼす水の硬度の影響
}

\author{
中川久機, 石尾真 弥
}

(1988 年 7 月 27 日受付)

\begin{abstract}
Effects of Water Hardness on the Toxicity and Accumulation of Cadmium in Eggs and Larvae of Medaka Oryzias latipes
\end{abstract}

Hisaki Nakagawa* and Shinya Ishio*

\begin{abstract}
Effects of water hardness on the toxicity and accumulation of $\mathrm{Cd}^{2+}$ in the eggs and the larvae of Oryzias latipes were studied. With increasing water hardness, the toxicity of $\mathrm{Cd}^{2+}$ on the eggs and the larvae decreased, also the amounts of $\mathrm{Cd}^{2+}$ accumulated by the eggs, the chorions and the larvae declined. On the other hand, the contents of $\mathrm{Ca}$ and $\mathrm{Mg}$ in the eggs and the chorions increased. Thus, the reason that the toxicity of $\mathrm{Cd}^{2+}$ on the eggs and the larvae were ameliorated with increasing water hardness is thought as follows: in hard water accumulation of $\mathrm{Cd}^{2+}$ by the eggs and the larvae will be suppressed since $\mathrm{Cd}^{2+}$ has to compete with $\mathrm{Ca}^{2+}$ and $\mathrm{Mg}^{2+}$ for active sites in the uptake channel.
\end{abstract}

既報りでは，カドミウムイオン (以下， $\mathrm{Cd}^{2+}$ と略記) の䓯性に対するメダカの卵・你期の感受性は卵の睬化 にともなって鋭敏になることを明らかにした。メダカの 卵拉よ゙仔魚に対する $\mathrm{Cd}^{2+}$ の毒性は，研究者によって 実験条件が異なるために，得られた結果は一様でない。 試験策件の中で大きく異なるのは供試の希积水の性質で ある。今までに, 希积本として, 硬度 $130 \mathrm{ppm}\left(\mathrm{CaCO}_{8}\right)$ の井水," ${ }^{1}$ 脱イオン水, ${ }^{2)}$ 脱塩素水道水 ${ }^{3,4)}$ が用いられ，そ れぞれ異なった結果が得られている。その原因は希积水 が含む無機イオン，特に，水の硬度成分にあると推測さ れる。

水の硬度が上昇すると魚類による $\mathrm{Cd}^{2+}$ の蓄積が低下 し，吊また， $\mathrm{Cd}^{2+}$ の毒性が低下することは，淡水魚の成 魚, ${ }^{\text {(10) }}$ ×ダカの卵111について報告されている。一方，仔 魚についてる硬度成分であるカルシウムイオン（以下， $\mathrm{Ca}^{2+}$ と略記) は $\mathrm{Cd}^{2+}$ の毒性を緩和し， $\mathrm{Cd}^{2+}$ の蓄積を 低下させる。

水の硬度が魚類の成魚汇対する重金属の毒性似影響す るのは， $\mathrm{Ca}^{2+}$ およびマグネシウムイオン (以下， $\mathrm{Mg}^{2+}$ 之略記）が魚類組織の活性部位をめぐって, 重金属イオ ンと競合するためと説明されている。 ${ }^{18)}$ 一方。魚類の卵 に対する $\mathrm{Cd}^{2+}$ の毒性発現は, まず卵莫に蓄積される

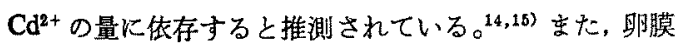
快陽イオン交換体の性質を有することがメダカおよび二
ジス卵膜で知られている。得って，水の硬度が焦類 の卵に対する $\mathrm{Cd}^{2+}$ の毒性発現に影響するのは，卵膜上 の結合部位をめぐって， $\mathrm{Cd}^{2+}$ と水の硬度成分である $\mathrm{Ca}^{2+}$ 於上び $\mathrm{Mg}^{2+}$ が競合するために，卵膜に拁ける $\mathrm{Cd}^{2+}$ の結合量比影䇾するからだと考光られる。

本研究では，魚卵について， $\mathbf{C d}^{2+}$ の毒性発現に対する

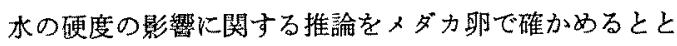
もに，仔魚については，水の硬度が $\mathrm{Cd}^{2+}$ の毒性拈よび 蓄耫性にいかなる影響を及ぼすか，メダカ仔魚で明らか にした。

\section{実験方法}

供試卵およひ仔魚 既報1) 飞述べた方法に従って, 胞

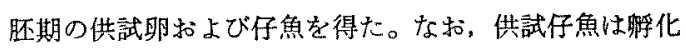
後 6 時間以内のものを用いた。

種々な硬度の希勫水の調製 小林 ${ }^{17)}$ は日本の河川水の 化学的な平均組成を調べた。その平均組成から計算する と, 日本の 223 の 1 級河川の平均的な水の硬度は 29.8 $\mathrm{ppm}\left(\mathrm{CaCO}_{3}\right)$ となった。をここでこの硬度をむつモデル 河川水の化学成分の中で, $\mathrm{Ca}^{2+}, \mathrm{Mg}^{2+}$, ナトリウムイオ ンおよびカリウムイオンの比率は同じにして, 試薬特級 (和光純薬) の $\mathrm{CaSO}_{4} \cdot 2 \mathrm{H}_{2} \mathrm{O}, \mathrm{CaCl}_{2} \cdot 2 \mathrm{H}_{2} \mathrm{O}, \mathrm{MgSO}_{4}$. $7 \mathrm{H}_{2} \mathrm{O}, \mathrm{NaCl}$ 括よび $\mathrm{KNO}_{3}$ を脱イオン水に溶かし, 硬 度 $298.0 \mathrm{ppm}\left(\mathrm{CaCO}_{8}\right)$ の希釈办の原液を調製した。そ

* 九州大学垔学部水産学科 (Department of Fisheries, Faculty of Agriculture, Kyushu University, Hakozaki, Higashi, Fukuoka 812, Japan). 
Table 1. Constituents of dilution water applied for the toxicity and accumulation tests on eggs and larvae of Oryzias latipes

\begin{tabular}{|c|c|c|c|c|c|}
\hline \multirow{2}{*}{$\begin{array}{c}\text { Hardness of } \\
\text { dilution water } \\
(\mathrm{ppm} \text { as } \mathrm{CaCO} \text { ) }\end{array}$} & \multicolumn{5}{|c|}{ Solute (ppm) } \\
\hline & $\mathrm{CaSO}_{4} \cdot 2 \mathrm{H}_{2} \mathrm{O}$ & $\mathrm{CaCl}_{2} \cdot 2 \mathrm{H}_{2} \mathrm{O}$ & $\mathrm{MgSO}_{4} \cdot 7 \mathrm{H}_{2} \mathrm{O}$ & $\mathrm{NaCl}$ & $\mathrm{KNO}_{3}$ \\
\hline 0 & 0 & 0 & 0 & 0 & 0 \\
\hline 3.0 & 2.6 & 1.0 & 1.9 & 1.7 & 0.3 \\
\hline 9.4 & 8.2 & 3.3 & 6.1 & 5.4 & 1.0 \\
\hline 29.8 & 25.8 & 10.3 & 19.3 & 17.0 & 3.1 \\
\hline 94.2 & 81.6 & 32.6 & 61.0 & 53.7 & 9.8 \\
\hline 298.0 & 258.0 & 103.0 & 193.0 & 170.0 & 31.0 \\
\hline
\end{tabular}

して脱イオン水でこの原液を希䣋し，Table 1 に示すよ らな 6 種類の硬度をもつ希釈水を調製した。これらの 希釈水は使用前に充分に通気した。

供試水の調製 既報 ${ }^{1}$ に述へた方法に往って，Cdと $し て 1 \mathrm{mg} / \mathrm{m} /$ の Cd 原液を希釈水で試験蹗度まで希釈 し，供陚水とした。なお，日本の大部分の河川は $\mathrm{pH}$ 6.9 7.2 の範囲内にあるので, ${ }^{17)}$ 本研究では供試水の $\mathrm{pH} 0.1 \mathrm{~N}$ の重炭酸ナトリウム溶液で, $7.0 \pm 0.1$ に調 節しだ。

卵および仔魚に対する嗇性試験 卵に対する $\mathrm{Cd}^{2+}$ の 毒性試験は， $50 \mathrm{ml}$ 容のガラスのビーカーに供試水 50 $\mathrm{m} l$ を取り，卵 25 個を入れて行った。そして卵の鞱化率 と $\mathrm{Cd}^{2+}$ 濃度との関保調べた。一方，存魚に対する $\mathrm{Cd}^{2+}$ の毒珄試跧は, $50 \mathrm{ml}$ 容のガラスのビーカーに供試 水 $50 \mathrm{ml}$ を取り，仔奥 10 尾を入れて行った。そして 5 日間に和ける瀂の異常症状の出現亡 $\mathrm{Cd}^{2+}$ 淟度との関 係を調ベた。両毒性試験ともに，試験区は各濃度 2 組ず つ設けそその結果は 2 組の平均値として表した。

卵之仔魚の金属イオン蓄皘試験 卵の $\mathrm{Cd}^{2+}, \mathrm{Ca}^{2+}$ 和 よび $\mathrm{Mg}^{2+}$ ，仔魚の $\mathrm{Cd}^{2+}$ 蓄皘性の試験には，1 $\mathrm{l}$ 容のカ ラスビーカーに試験水 $1 l$ を取り，卵 300 個または仔重 300 星を入れ，適当な时間間隔で卵 50 個ずつ，または 仔魚 50 尾ずつを取り上げ，脱イオン水でよく洗い，畉 の $\mathrm{Cd}, \mathrm{Ca}$ 扰よび $\mathrm{Mg}$ の分析用試料，仔魚の $\mathrm{Cd}$ 分析 用試料とした。をれらの試料には死卵，死仔魯は含ぬな かった。また，卵膜を通過して则の内部に蓄栍された

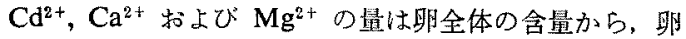
膜の含量を差し引いて求めた。乞のための即および卵膜 試料は，供試眼妾二分し，一方は畉全体の金属分析用試 料とし，他力は眀を濾綎心間で押しつぶして，卵の内容 物を除き，得られた卵膜を分析用試料とした。卵の金属 イオン蓄積試験は各試験区 3 組ずつ設け，々の結果は

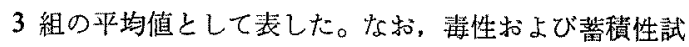
験ともに，供試水は2 日毎に換えた。試験温度は $21 \sim$ $25^{\circ} \mathrm{C}$ とした。

卵, 卵膜および仔魚の金属定量法 卵，仔魚および卵膜
の分析用試料は，既報 》に述べた方法に従って，王水一 過塩素酸に上万湿式灰化後，水分を蒸発させ，残渣を $0.5 \mathrm{~N}$ 塩酸溶液に溶解した。そして， Cd の定量の場合， $こ の$ 塩酸液中の $\mathrm{Cd}^{2+}$ 濃度を直接原子吸光法で湘定し た。 ${ }^{18)}$ 东た， $\mathrm{Ca}$ および $\mathrm{Mg}$ の定量の場合，この塩酸浴 液を直接原子吸光法で定量すると，卵の分解産物による 定舅の妨害が認められたので，Willis ${ }^{18)}$ の方法に従って， 畉の分解物の $0.5 \mathrm{~N}$ 塩酸溶液 $4.5 \mathrm{ml}$ K原子吸光分析用 の $10 \%$ 塩化ランタン溶液 (和光純薬製) $0.5 \mathrm{ml}$ を加光, 卵の分解産物による定量の妨害を除いた。

\section{結 果}

卵に対する $\mathrm{Cd}^{2+}$ の毒性と水の硬度の影敕 種々な硬 度をもった供試水に招けるメダカ畉の睬化に対方 $\mathrm{Cd}^{2+}$ の影響試験の結果を Table 2 に示した。卵の艀化 に対与る $\mathrm{Cd}^{2+}$ の影響は硬度 0, 3.0, 9.4 およひ 29.8 ppm $\left(\mathrm{CaCO}_{3}\right)$ で，それでれ 0.1，1.0，3.0 および 10.0 ppm の $\mathrm{Cd}^{2+}$ 濃度から現われた。しかし硬度 94.2 拈よ び $298.0 \mathrm{ppm}\left(\mathrm{CaCO}_{3}\right)$ の水では, $10.0 \mathrm{ppm} の \mathrm{Cd}^{2+}$ 濃 度で名卵の胚発生に影響は認められなかった。即ち，卵 の肧発生に対して $\mathrm{Cd}^{2+}$ の姜性は水の硬度の上开ととる に低下した。

仔魚に対する $\mathbf{C d}^{2+}$ の毒性と水の硬度の影響 種々な 硬度をるった供試水に打ける仔魚への $\mathrm{Cd}^{2+}$ の影響を Fig. 1 に示した。既報りにおいてひ触れたが，你魚のCd 中毒恃初期では不規則な遊泳，狂故に始まり，平衡を失 い横転する。この段階でピベットによる水流などの機械 的な刺激を与えると反応して㾏奔を始める。しかし中毒 が進さとこのよらな機械的な刺激にる反応しなくなり， 死に至る。そこで，仔魚の $\mathrm{Cd}$ 中毒の程度を 1) 機㑘的 な刺激に対して反応的，2）非反応的，3）致死的と分忛 た。仔魚に対与る $\mathrm{Cd}^{2+}$ の影慜は硬度 9.4, 29.8,94.2 打 上び $298.0 \mathrm{ppm}\left(\mathrm{CaCO}_{3}\right)$ で，それぞれ 0.01, 0.03, 0.10 拈よび $1.0 \mathrm{ppm} の \mathrm{Cd}^{2+}$ 濃度から現れた。即ち，仔魚に 対する $\mathrm{Cd}^{2+}$ の毒性は水の硬度の上昇によって低下し た。 
Table 2. Percent hatchabilities of eggs of Oryzias latipes exposed to test solutions consisting of combinations of seven $\mathrm{Cd}^{2+}$ concentrations and six levels of water hardness

\begin{tabular}{crrrrrrr}
\hline $\begin{array}{c}\text { Hardness of } \\
\text { test water } \\
(\mathrm{ppm} \text { asCaCO }\end{array}$ & \multicolumn{7}{c}{$\mathrm{Cd}^{2+}$ concentration of test water (ppm) } \\
\hline 0 & $\mathbf{0}$ & $\mathbf{0 . 0 3}$ & $\mathbf{0 . 1}$ & 0.3 & 1.0 & 3.0 & 10.0 \\
\hline 3.0 & 96 & 100 & 80 & 0 & 0 & 0 & 0 \\
9.4 & 94 & 98 & 100 & 100 & 66 & 0 & 0 \\
29.8 & 98 & 100 & 94 & 98 & 100 & 32 & 0 \\
94.2 & 100 & 94 & 98 & 100 & 100 & 98 & 6 \\
298.0 & 96 & 96 & 100 & 98 & 100 & 98 & 96 \\
& 96 & 98 & 92 & 92 & 98 & 100 & 98 \\
\hline
\end{tabular}

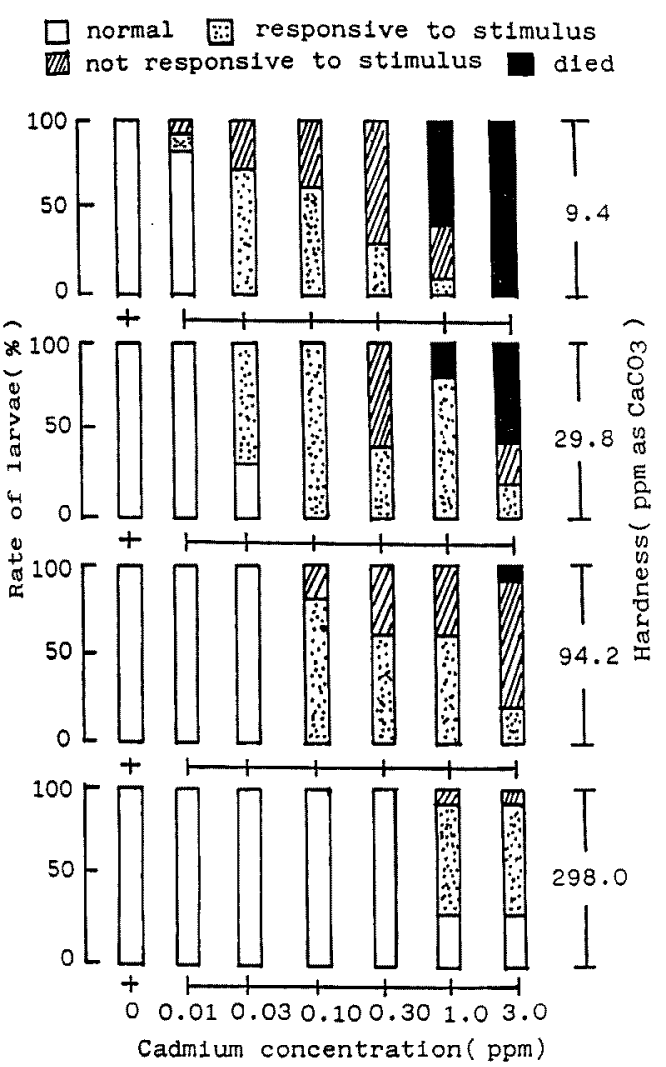

Fig. 1. Rates of normal and abnormal larvae of Oryzias latipes exposed for five days to test solutions consisting of combinations of four levels of water hardness and seven $\mathrm{Cd}^{2+}$ concentrations.

卵, 卵膜および卵内部の $\mathbf{C d}^{2+}$ 蕃䅪 $0,29.8$ おょび $298.0 \mathrm{ppm}\left(\mathrm{CaCO}_{3}\right)$ の硬度の希釈水で調製した $3.0 \mathrm{ppm}$ の $\mathrm{Cd}^{2+}$ 供試水に卵を保温した時, 卵, 卵膜挹上び卵内 部における $\mathrm{Cd}^{2+}$ の蓄積状況を Table 3 亿示した。即, 㽗膜および卵内部の蓄積量は，いずれる水の硬度の上界

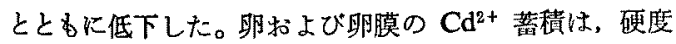
$0 \mathrm{ppm}\left(\mathrm{CaCO}_{8}\right)$ の場合は経時的に增加したが，硬度 29.8
および $298.0 \mathrm{ppm}\left(\mathrm{CaCO}_{3}\right)$ の場合，最初は経時的に減 少したものの 24〜48 時間後にはほぼ一定值に達した。 とれに対して卵内部の $\mathrm{Cd}^{2+}$ 蓄積は, 硬度 $0 \mathrm{ppm}$ $\left(\mathrm{CaCO}_{3}\right)$ の場合はやはり経時的に增加したが，硬度 29.8 拉よび $298.0 \mathrm{ppm}\left(\mathrm{CaCO}_{3}\right)$ の場合は経過時間に関倸な くほぼ一定值を示した。なお，硬度 $0 \mathrm{ppm}\left(\mathrm{CaCO}_{3}\right)$ の 場合は 48 時間後にははとんどの卵が䇥死しだ。

\section{卵, 卵膜および畉内部の $\mathrm{Ca}^{2+}$ および $\mathbf{M g}^{2+} \mathrm{Cd}^{2+}$} 濃度 $3.0 \mathrm{ppm}$, 硬度 $0,29.8$ 抢上び $298.0 \mathrm{ppm}\left(\mathrm{CaCO}_{3}\right)$ を子つ供試办中に卵を保温した時，卵，卵膜括よび卵内

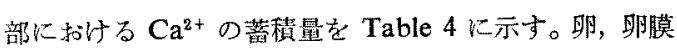
および卵内部の $\mathrm{Ca}^{2+}$ の蓄積量は水の硬度の上昇ととも に増大したが，経時的には增大せず，ほぼ一定の值であ った。いずれの水の硬度でる, 卵内部の Ca 含量は卵膜 のCa量と比べると高い值であった。硬度 $0 \mathrm{ppm}$ $\left(\mathrm{CaCO}_{s}\right)$ の場合, 供試水に $\mathrm{Ca}^{2+}$ は存在しないので, 卵 による水中の $\mathrm{Ca}^{2+}$ の蓄積术こらない。従って, 硬度 $0 \mathrm{ppm}\left(\mathrm{CaCO}_{3}\right)$ の卵の $\mathrm{Ca}$ 弪試験前からむともと存在 していたことになる。

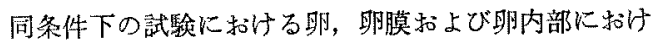
る $\mathrm{Mg}^{2+}$ の蓄積量を Table 5 と示す。卵，卵膜拉よび 卵内部の $\mathrm{Mg}^{2+}$ 苗積量は, 便度 29.8 おっよ゙ $298.0 \mathrm{ppm}$ $\left(\mathrm{CaCO}_{3}\right)$ の場合はほぼ同し值であったが，この両方の值 は，硬度 $0 \mathrm{ppm}\left(\mathrm{CaCO}_{3}\right)$ の場合飞抬ける卵の $\mathrm{Mg}^{2+}$ 蓄程量よりもやや高い值であった。卵，卵膜および畉内 部の $\mathrm{Mg}^{2+}$ 落積は，いずれの水の硬度でる経時的には増 大せず，ほぼ一定の值であった。また，いずれの水の硬 度でる, 卵内部の $\mathrm{Mg}$ 含量は卵膜の $\mathrm{Mg}$ 量と比べると 高い值であった。硬度 $0 \mathrm{ppm}\left(\mathrm{CaCO}_{3}\right)$ の場合，供試水 に $\mathrm{Mg}^{2+}$ 恃存在しないので, 卵飞よる水中の $\mathrm{Mg}^{2+}$ の蓄 積休起こらない。従って, 硬度 $0 \mathrm{ppm}\left(\mathrm{CaCO}_{3}\right)$ の卵の $\mathrm{Mg}$ は陚験前からるともと存在していたことになる。

仔魚の $\mathrm{Cd}^{2+}$ の蓄皘 種々な硬度をもつ $3.0 \mathrm{ppm} の$ $\mathrm{Cd}^{2+}$ 滥度の供試水に仔魚を保温した时, 仔魚による $\mathrm{Cd}^{2+}$ 蓄皘量の経時的な变化を Fig. 2 に示した。仔魚に よる $\mathrm{Cd}^{2+}$ の苗積量は水の硬度の上昇とともに低下し， 
Table 3. Accumulation of $\mathrm{Cd}^{2+}$ in eggs of Oryzias latipes exposed to water solutions with $\mathrm{Cd}^{2+}$ concentration of $3.0 \mathrm{ppm}$ and different levels of water hardness

\begin{tabular}{|c|c|c|c|c|}
\hline \multirow{2}{*}{$\begin{array}{c}\text { Hardness } \\
\text { of test water } \\
\left(\mathrm{ppm} \text { as } \mathrm{CaCO}_{3}\right)\end{array}$} & \multirow{2}{*}{$\begin{array}{c}\text { Duration of } \\
\text { exposure } \\
\text { (hours) }\end{array}$} & \multicolumn{3}{|c|}{ Cd content (ngCd/egg)* } \\
\hline & & Intact egg (A) & Chorion (B) & Insides (A-B) \\
\hline \multirow[t]{3}{*}{0} & 6 & 360.7 & 236.0 & 124.7 \\
\hline & 12 & 491.3 & 271.0 & 220.3 \\
\hline & 24 & 581.0 & 311.5 & 269.5 \\
\hline \multirow[t]{5}{*}{29.8} & 6 & 238.6 & 191.6 & 47.0 \\
\hline & 12 & 227.7 & 185.3 & 42.4 \\
\hline & 24 & 227.7 & 175.3 & 52.4 \\
\hline & 48 & 185.2 & 135.6 & 49.6 \\
\hline & 72 & 179.0 & 137.0 & 42.0 \\
\hline \multirow[t]{5}{*}{298.0} & 6 & 88.2 & 84.4 & 3.8 \\
\hline & 12 & 78.6 & 72.4 & 6.2 \\
\hline & 24 & 64.4 & 59.5 & 4.9 \\
\hline & 48 & 71.6 & 61.4 & 10.2 \\
\hline & 72 & 54.3 & 50.5 & 3.8 \\
\hline
\end{tabular}

* Values are the mean of three replicates.

Table 4. Ca contents in eggs of Oryzias latipes exposed to test solutions with $\mathrm{Cd}^{2+}$ concentration of $3.0 \mathrm{ppm}$ and different levels of water hardness

\begin{tabular}{ccccc}
\hline \hline \multirow{2}{*}{$\begin{array}{c}\text { Hardness } \\
\text { of test water } \\
(\mathrm{ppm} \text { as CaCO} \text { ) }\end{array}$} & $\begin{array}{c}\text { Duration of } \\
\text { exposure } \\
\text { (hours) }\end{array}$ & Intact egg (A) & Chorion (B) & Insides (A-B) \\
\cline { 3 - 5 } & 6 & 476.0 & 13.1 & 462.9 \\
& 12 & 436.8 & 17.7 & 419.1 \\
29.8 & 24 & 478.8 & 14.0 & 464.8 \\
& 6 & 586.7 & 55.4 & 531.8 \\
& 12 & 549.3 & 51.6 & 497.7 \\
& 24 & 576.0 & 51.6 & 524.4 \\
298.0 & 48 & 581.3 & 38.2 & 543.1 \\
& 72 & 594.7 & 47.1 & 547.6 \\
& 6 & 653.0 & 75.1 & 577.9 \\
& 12 & 653.6 & 75.1 & 577.9 \\
& 24 & 705.8 & 66.5 & 639.3 \\
& 48 & 620.4 & 65.3 & 555.1 \\
\end{tabular}

* Values are the mean of three replicates.

Table 5. Mg contents in eggs of Oryzias latipes exposed to test solutions with $\mathrm{Cd}^{2+}$ concentration of $3.0 \mathrm{ppm}$ and different levels of water hardness

\begin{tabular}{ccccc}
$\begin{array}{c}\text { Hardness } \\
\text { of test water } \\
\text { (ppm as CaCO }\end{array}$ & $\begin{array}{c}\text { Duration of } \\
\text { exposure } \\
\text { (hours) }\end{array}$ & Intact egg (A) & Chorion (B) & Insides (A-B) \\
\hline 0 & 6 & 282.4 & 6.8 & 275.6 \\
& 12 & 278.4 & 8.8 & 269.6 \\
29.8 & 24 & 296.8 & 8.2 & 288.6 \\
& 6 & 318.4 & 16.1 & 302.3 \\
& 12 & 309.6 & 12.2 & 297.4 \\
& 24 & 318.4 & 13.5 & 304.9 \\
& 48 & 308.8 & 9.3 & 299.5 \\
& 72 & 309.6 & 12.3 & 297.3 \\
& 6 & 307.2 & 16.9 & 294.3 \\
& 12 & 313.6 & 19.5 & 289.5 \\
& 24 & 306.4 & 16.9 & 308.5 \\
& 48 & 325.6 & 17.1 & 286.8 \\
\hline
\end{tabular}

\footnotetext{
* Values are the mean of three replicates.
} 


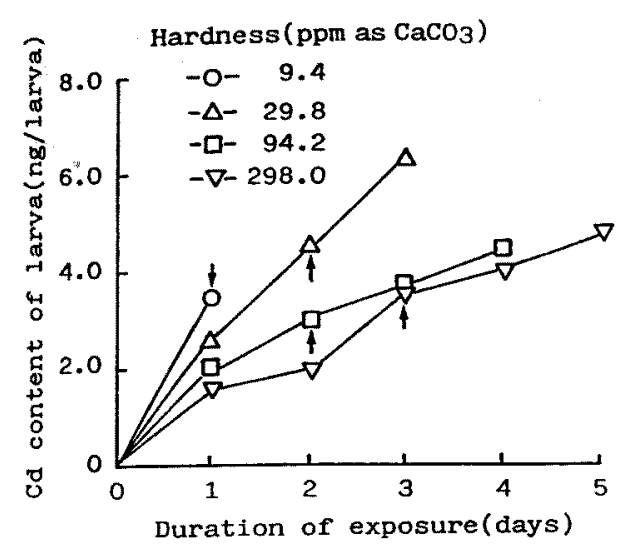

Fig. 2. Accumulation of $\mathrm{Cd}^{2+}$ by larvae of Oryzias latipes exposed to test solutions with $\mathrm{Cd}^{2+}$ concentration of $3.0 \mathrm{ppm}$ and different levels of water hardness. Arrows indicate the emergency of $\mathrm{Cd}$ intoxication on the larvae.

経時的に增大した。仔魚の $\mathrm{Cd}$ 中毒症状は仔魚が個体当 り 3 4 ng のCd 蓄積すると現われた。そして水の硬 度か上昇すると保魚の Cd 中毒症状は漣れて現われた。

\section{考察}

メダカ卵の餒化に対する $\mathrm{Cd}^{2+}$ の毒性は水の硬度の上 昇によって低下した (Table 2)。 Michibata ${ }^{11)}$ む水の硬 度の上昇はィダカ眃に対する $\mathrm{Cd}^{2+}$ の毒性を低下させる と報告している。ねダカ卵の脬化に対する $\mathbf{C d}^{2+}$ の影響 は，希釈水として脱イオン水を用いた場合，0.06 0.30 ppm の $\mathrm{Cd}^{2+}$ 漉度で現われ，2)本研究の希釈水として硬 度 $0 \mathrm{ppm}\left(\mathrm{CaCO}_{3}\right)$ の場合とほぼ同じ結果であった。 た, メタ゚カ卵の瞬化に対する $\mathrm{Cd}^{2+}$ の毒性は, 既報1)飞述 ベたように，硬度 $130 \mathrm{ppm}\left(\mathrm{CaCO}_{8}\right)$ に希釈した井水を 用いた場合， $4.0 \mathrm{ppm}$ の $\mathrm{Cd}^{2+}$ 濃度で認められたが，本 研究では硬度が 94.2 打よび $298.0 \mathrm{ppm}\left(\mathrm{CaCO}_{3}\right)$ の場 合, $10 \mathrm{ppm} の \mathrm{Cd}^{2+}$ 渡度です現われなかった。この違い

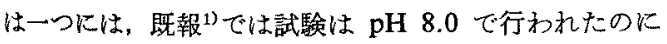
対し，本研究では pH 7.0 で行われた。徉って，供試水 の $\mathrm{pH}$ ，西るい性多くの化学成分を含んでいる井水々簡 単极成分の人工希釈水の差異が $\mathrm{Cd}^{2+}$ の毒性の違いとし て現かれたるのと考光られる。

タダカの卵, 卵膜招上び卵内部による $\mathrm{Cd}^{2+}$ の蓄積は, 水の硬度が上昇すると低下した (Table 3)。魚類甈によ る $\mathrm{Cd}^{2+}$ の蓄積性が水の硬度打上び塩分澧度の上昇によ って低下することは，数種の魚類の畉で報告されてい る。 その蓄積量は水の硬度の上昇とともに低下した（Table 3)。そ机対して，卵膜に打ける $\mathrm{Ca}^{2+}$ 打よび $\mathrm{Mg}^{2+}$ の 蓄積は水の硬度の增大ととむに增大した (Tables 4,5 )。
従って、卵膜の篦㺓部位をめぐって, $\mathrm{Cd}^{2+}$ と $\mathrm{Ca}^{2+}$ 或は $\mathrm{Cd}^{2+} \varepsilon \mathrm{Mg}^{2+}$ が競合するために，水の硬度の增大によ って, 卵膜に和活る $\mathrm{Cd}^{2+}$ の蓄積量が低下したものと判 断できる。そして卵膜の $\mathrm{Cd}^{2+}$ 蓄積量の低下が，卵膜を 通して卵の内部に堛積する $\mathrm{Cd}$ 量を低下させたと考えら れる (Table 3)。メダカ即についてのこのような試駼結 果から，従来，推測されていた魚類の㽗に対する $\mathrm{Cd}^{2+}$ 毒性発現機構が正しいことを示唆している。Michi-

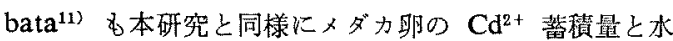
の硬度との間汇逆相関関係が存在する結榡を得心。

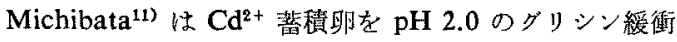
液で洗深した後, 卵の Cd 含量を定量し，その值を阫の $\mathrm{Cd}$ 含量とした。先して肧の Cd 含量は水の硬度に影響 されずに，一定であると報告した。しかし本研究では， Table 3 亿示寸上弓に, 即内部の $\mathrm{Cd}$ 含量は水の硬度の 增大とともに低下し，Michibata ${ }^{11)}$ の結果と著しく異な った。C $\mathrm{Cd}^{2+}$ がメダカ畉を死に導くことについて Michibata ${ }^{(1)}$ は，卵膜に吸着した $\mathrm{Cd}^{2+} か ゙$ 何らかの機構を通し

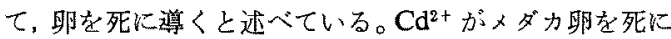
導くに恃原に達した Cdの量が閣題となる。しかし本研 究では，卵内部の $\mathrm{Cd}$ 含量を間接的方法で測定してい

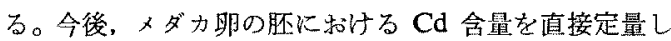
て， $\mathrm{Cd}^{2+}$ が卵を死へ導く正確な機構を明らかにする必 要がある。なお゙，硬度 29.8 および $298.0 \mathrm{ppm}\left(\mathrm{CaCO}_{8}\right)$ の場合，卵の $\mathrm{Cd}^{2+}$ 蓄積量は最初経時的に減少した (Table 3)。乙かし既報1,18) 飞述べたよらに，メダカ卵の $\mathrm{Cd}^{2+}$ 蓄積量は最初経時的に減少することるなく，24〜 48 時間で，ピーク汇達し，その状態を維持し，本研究の 結果と多少異なった。本研究で，卵の $\mathrm{Cd}^{2+}$ 蓄積量が最 初経時的に減少したが，その理由は明らかでない。

メダカの瀂住対する $\mathrm{Cd}^{2+}$ の毒性は，水の硬度が增 大するとともに低下した (Fig. 1)。末た，メダカの仔魚 による $\mathrm{Cd}^{2+}$ の蓄積速度は水の便度の上昇ととも几低下 したが，蓄積量は時間とともに增大した（Fig. 2)。一方， striped bass の稚魚でる水の硬度成分である $\mathrm{Ca}^{2+}$ 簧度 の增大任 $\mathrm{Cd}^{2+}$ の毒性を緩和し， $\mathrm{Cd}^{2+}$ の蓄積を低下させ た。 ${ }^{12)}$ 従って, メダカ仔魚による $\mathrm{Cd}^{2+}$ の蓄積は水の硬 度成分である $\mathrm{Ca}^{2+}$ および $\mathrm{Mg}^{2+}$ の蓄積と捛抗すること が明らかであり，メダカ仔魚による $\mathrm{Cd}^{2+}$ の荋積経路は $\mathrm{Ca}^{2+}$ 怙よび $\mathrm{Mg}^{2+}$ の蓄積経路之類似していることを示

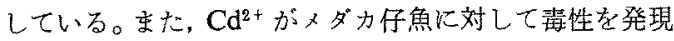
するためには仔魚にある量以上の $\mathrm{Cd}^{2+}$ が箈積すること が必要である。メダカ仔魚の $\mathrm{Cd}^{2+}$ 蓄積量が時間ととる に增大するので， $\mathbf{C d}^{2+}$ の低瀑度でる仔魚を長期間飼育 すると，仔魚に Cd 中毒を発現する汇必要な Cd 量が蓄 積することが推測される。

以上の研究結果から，水の硬度が上昇するとメダカの 
卵括よび\}魚に対する $\mathrm{Cd}^{2+}$ の毒珄は低下した。メダカ の成魚 ${ }^{8)}$ 扰よび前述したょうに, 他種類の成魚でも同様 であった。従って， $\mathrm{Cd}^{2+}$ の毒性が水の硬度の上界に上っ て低下寸るといらことは魚類の全生育段階に適用でさる ことを示唆している。

\section{文塥}

1) 中川久機，石尾真弥：日水誌，54，2153-2158 (1988).

2) 青木一子：動雜, 87, 91-97 (1978).

3) 平岡幸夫: 生態化学, 4, 31-36 (1981).

4) 藤井滩文, 杉山傢一: 生態化学, 6, 9-16 (1983).

5) M. L. Kinkade and H.E. Erdman: Environ. Res., 10, 308-313 (1975).

6) Q. H. Pickering and C. Henderson: Air Wat. Pollut. Int. J., 10, 453-463 (1966).

7) V. M. Brown: Water Res., 2, 723-733 (1968).

8）田端健二: 東海水研報，No. 58, 215-232 (1969).

9) L. S. McCarty, J.A. C. Henry, and A. H. Houston: J. Fish. Res. Bd. Can., 35, 35-42 (1978).

10) J. J. Carroll, S. J. Ellis, and W. S. Oliver: Bull.
Environ. Contam. Toxicol., 22, 575-581 (1979).

11) H. Michibata: Bull. Environ. Contam. Toxicol, 27, 187-192 (1981).

12) D. A. Wright, M. J. Meteyer, and F. D. Martin: Bull. Environ. Contam. Toxicol., 34, 196-204 (1985).

13) V. Zitko and W. G. Carson: Chemosphere, 5, 299-303 (1976).

14) H. Rosenthal and K. R. Sperling: in "The Early Life History of Fish" (ed. by J.H. S. Blaxter), Springer, Berlin, 1974, pp. 383-396.

15) H. Westernhagen, H. Rosenthal, and K. R. Sperling: Helgol. Wiss. Meeresunters., 26, 416-433 (1974).

16）中川久機，石尾真弥：日水誌，55, 123-129 (1989).

17) 小林 純: 用水と廃水, 2, 9-24 (1960).

18）中川久機，石尾真弥：日水誌， 54，2159-2164 (1988).

19) J. B. Willis: Anal. Chem., 33, 556-559 (1961).

20) H. Westernhagen and V. Dethlefsen: J. Mar. Biol. Ass. U. K., 55, 945-957 (1975).

21) H. Westernhagen, V. Dethlefsen, and H. Rosenthal: Helgol. Wiss. Meeresunters., 27, 268-282 (1975). 